\title{
STUDENTS' VOCATIONAL HIGH SCHOOL MISCONCEPTION REVIEWED FROM WRITTEN MATHEMATICAL COMMUNICATION ABILITY
}

\author{
Radiusman $^{1^{*}}$, Yurniwati ${ }^{2}$, Maslina Simanjuntak ${ }^{3}$, Rizki Jamiatul Sabariyah ${ }^{4}$, Iva \\ Nurmawanti ${ }^{5}$ \\ ${ }^{1,5}$ Department of Primary School Teacher Education, Universitas Mataram, Indonesia \\ ${ }^{2}$ Department of Primary School Teacher Education, Universitas Negeri Jakarta, Indonesia \\ ${ }^{3}$ Department of Mathematics Education, Universitas Negeri Surabaya, Indonesia \\ ${ }^{4}$ SMK Negeri 1 Purwasari, Indonesia \\ *Corresponding author: radius_saragih88@unram.ac.id
}

\begin{tabular}{|c|c|}
\hline Article Info & ABSTRACT \\
\hline Article history: & \multirow{8}{*}{$\begin{array}{l}\text { This qualitative research aims to describe students' misconceptions } \\
\text { in linear programming reviewed from written mathematical } \\
\text { communication ability. Four students from grade X SMKN } 1 \\
\text { Purwasari were selected as research subjects by purposive } \\
\text { sampling. Data collected through observation and essay tests. The } \\
\text { results showed that the sample students experienced } \\
\text { misconceptions in the low and high categories. Misconception with } \\
\text { high categories lies in the indicators of changing mathematical } \\
\text { ideas into mathematical models }(75 \%) \text {, represent mathematical } \\
\text { ideas into images or vice versa (100\%), and mathematical problem- } \\
\text { solving procedures ( } 75 \%) \text {, while misconception with low } \\
\text { categories is found in indicators choose the right concept in solving } \\
\text { mathematical problems }(25 \%) \text {. Based on this result, further } \\
\text { treatment is needed to overcome students' misconceptions before } \\
\text { students continue learning to a higher stage. }\end{array}$} \\
\hline Received: March 16, 2020 & \\
\hline Accepte & \\
\hline d: July 31, 2020 & \\
\hline Keywords: & \\
\hline & \\
\hline Mathematics communication & \\
\hline Misconception & \\
\hline
\end{tabular}

\section{MISKONSEPSI PESERTA DIDIK SEKOLAH MENENGAH KEJURUAN DITINJAU DARI KEMAMPUAN KOMUNIKASI MATEMATIKA TERTULIS}

Kata Kunci:
Pemrograman linear
Komunikasi matematika
Miskonsepsi

ABSTRAK

Penelitian kualitatif ini bertujuan untuk mendeskripsikan miskonsepsi peserta didik dalam topic program linear ditinjau dari kemampuan komunikasi matematika tertulis. Empat siswa dari kelas X SMKN 1 Purwasari dipilih sebagai subjek penelitian secara purposive sampling. Data dikumpulkan melalui observasi dan soal tes uraian. Berdasarkan hasil penelitian, subjek dikonfirmasi mengalami miskonsepsi dengan kategori rendah dan tinggi. Miskonsepsi dengan kategori tinggi terletak pada indikator mengubah ide matematika ke dalam model matematika (75\%), merepresentasikan ide matematika ke dalam gambar atau sebaliknya (100\%), dan menuliskan prosedur penyelesaian masalah matematika (75\%), sedangkan miskonsepsi dengan kategori rendah terdapat pada indikator memilih konsep yang tepat dalam menyelesaikan masalah matematika (25\%). Berdasarkan penelitian ini, diperlukan perlakuan lanjutan untuk mengatasi miskonsepsi siswa sebelum melanjutkan ke tahap yang lebih tinggi. 


\section{INTRODUCTION}

Concept understanding becomes an important ability needed by students to solve mathematical problems. Concept understanding is also an important part in the problem solving process [1]. Concept understanding in mathematics is built on an ongoing basis and begins by defining an object and followed by calculations [2]-[5]. Students are considered capable to understand a mathematical concept when they are able to group or associate or distinguish any mathematical objects that are part of a group or not part of a group, for example students who already understand the concept of linear equations will be able to group equations that are linear line (straight line) and not linear (curve). Students who have a good concept understanding will also be able to communicate their ideas accurately, completely and correctly. But there are still many students who experience misconceptions in solving math problems. This thing happens because there are still many learning processes that are centered on the teacher [6], [7]. The teacher should be able to create an attractive learning atmosphere in the classroom, so learning is not only centered on the teacher [8], because learning that is not attractive will cause students to be less active in participating in learning activities in the classroom.

Misconception is a wrong mental attitude in understanding a thing (concept) [9]. Misconception is the naive knowledge of students so that they are resistant to change [10]. Misconception is caused by the learning experience that students go through in the previous class, including: the teacher is too demanding students to connect each concept so that students tend to choose to memorize the concept [11], [12], students' discomfort with teacher's technique in teaching mathematics causes students to only observe patterns and make their own conclusions [13] and incomplete information received by students is also one of the factors causing misconceptions [14]. Physiologically, misconceptions are very common in students and are very disruptive to their learning abilities [9]. isconceptions in mathematics can make it difficult for students to solve problems and express their ideas [15]. Besides, misconception can also make students difficult in mastering the lesson [16].

Continuous misconception will lead to increasingly complex misconception among students [17], [18], thus, causing continuing mistakes [19]. Teachers will find it difficult to fix students' understanding of a concept that has experienced misconception, because changing students' misconceptions means changing students' basic thinking that they think is right. Misconception must be overcome immediately because it will be one of the causes of students' mistakes in solving mathematical problems [20] and also one of the causes of low learning outcomes [17].

There are three types of students' mistakes in working on problems, i.e. algorithm errors, concept errors, and errors due to lack of accuracy [21]. Although the misconceptions that occur in students have been going on for a long time, the level of misconception of each student is not the same. Students' misconception levels can be divided into several levels: low, medium and high. Low-level misconception occur when students are able to answer questions only by showing some of the concepts that are mastered without misunderstanding, medium-level misconception occur when students answer with the correct concept but cannot show the reason for using the concept, high-level misconception occur when students are able to answer the problem but with explanations that do not make sense [16]

Students' misconceptions on the topic of linear programming are very diverse. Many students are not able to determine the value of the maximum function of an inequality, students are not able to make line equations, students experience calculation errors and are unable to solve problems [22]. Besides, students do not have a clear explanation about the

134 Indonesian Journa 1 of Science and M athematics Education ( I J S M E) 
definition of linear programming, how to classify inequalities and not inequalities, students are also unable to make mathematical models and have errors in problem solving [23]. Students mistakes in making mathematical models, choosing the right concepts to write procedures for completing mathematical models, representing mathematical ideas into pictures, and writing mathematical completion procedures, are characteristics of weaknesses in written mathematical communication, because those things are indicators of written mathematical communication ability [24].

Based on the results of the pre-research conducted at SMK Negeri 1 Purwasari, it was found that some students experienced low and high misconceptions in solving linear programming problems reviewed from written mathematical communication abilities. Students' misconception on linear programming include determining the inequality symbol that represents the mathematical model and determining the answer for the problem. One example of misconception experienced by student in solving linear programming problem can be seen in Figure 1.

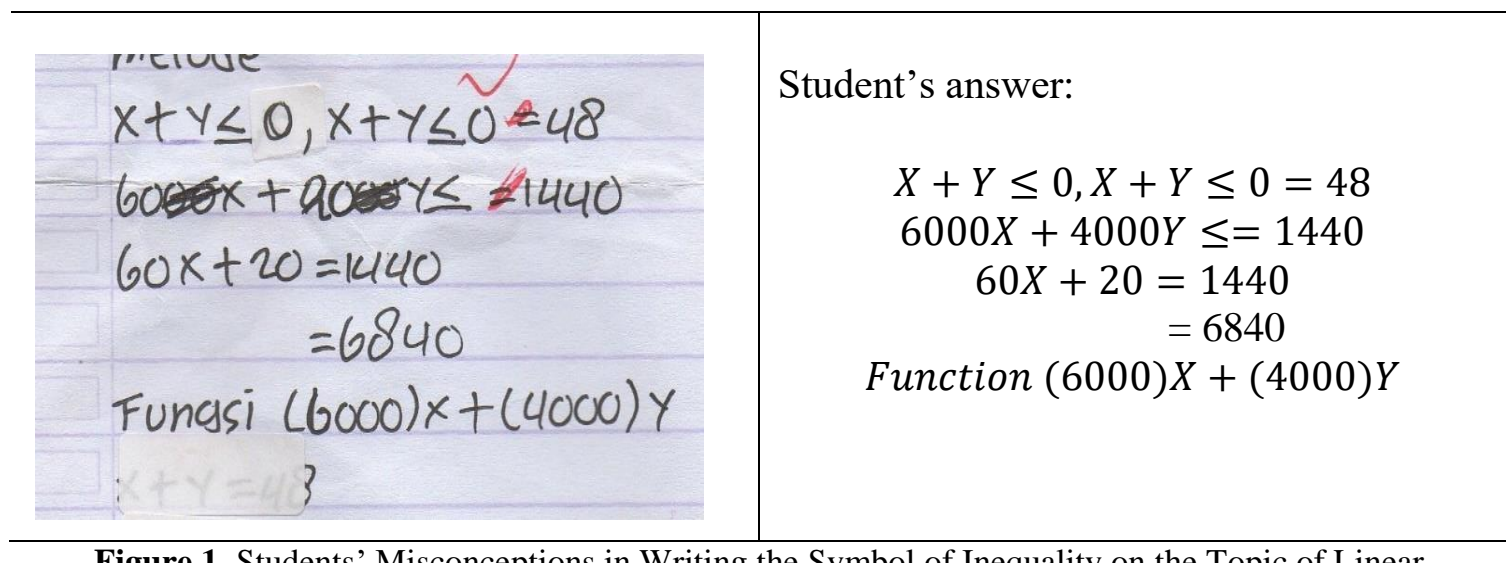

Figure 1. Students' Misconceptions in Writing the Symbol of Inequality on the Topic of Linear Programming

Figure 1 shows that students experience confusion (not understanding) about the use of inequality symbol caused by the lack of understanding about using the symbol "smaller than", "greater than", "less than", "more than", "at least" and "mostly". Good understanding of inequality concept will help students to better understand the meaning of the inequality symbol [25], [26]

Based on the description above, this research will describe the misconception that often happen in students in the topic of linear programming in terms of students' written mathematical communication skills. This research is important to do because if misconceptions among students are high and ongoing, it will affect the ability of students to understand further concept [16], solve mathematical problems procedurally [27] and causing disruption of students' learning abilities physiologically [9] which will cause student learning outcomes to be low [28].

Research on misconception has been found in various scientific publishing portals, including research on misconceptions on the concept of mathematical logic in terms of presuppositions [29], misconception in decimal numbers [28], misconception in algebraic inequality [25], [30], misconceptions experienced by teachers and students in understanding the equation [31], students' misconception in completing the limit function [16], and misconception about the elements of geometry [27], [32], [33]. Misconception research on linear programs already exists, but only discuss the impact of Realistic Mathematics Learning approaches on students' misconceptions on linear programs, so this 
study will discuss studentss misconception in solving linear programming problems reviewed from written mathematical communication skills.

\section{METHOD}

The method in this research is descriptive qualitative. Descriptive qualitative analysis focuses on describing students' misconception reviewed from written mathematical communication skills and explaining the causes of students experiencing misconception in solving mathematical problems. This research uses observation and tests to collect research data. This research took place at SMK 1 Purwasari by taking four students from class X of the Accounting Department as research subjects, all four samples were selected based on written mathematical communication ability in medium level. So that in this study the research subjects were selected by purposive sampling. The study begins by providing essay questions with linear programming topic to students, each question has 4 sub-questions, where each question contains one indicator of written mathematical communication ability.

The indicators of written mathematical communication skills are: 1) changing mathematical ideas into mathematical models such as: writing a mathematical equation to express a mathematical idea; 2) choosing the right concept in solving mathematical problems; 3) represent mathematical ideas into pictures or vice versa, and 4) write procedures for solving mathematical problems.

Research procedures to find out more about students' misconception can be seen in Figure 2 below.

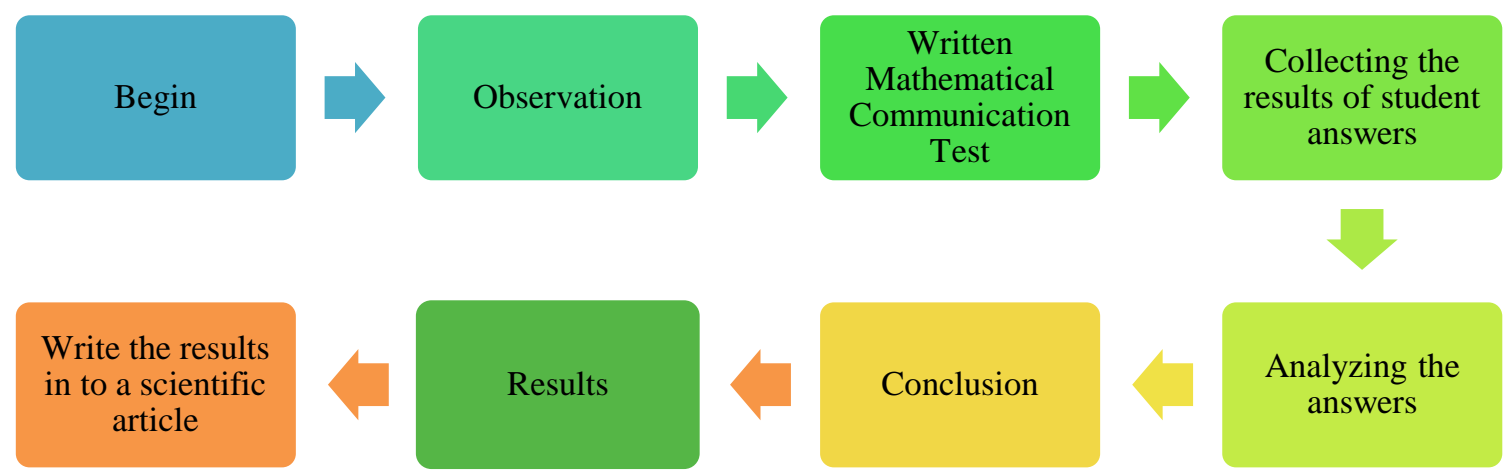

Figure 2. Research Procedure

Through students' answers, we can elaborate students' misconception in solving linear programming problems in terms of written mathematical communication ability indicators. The level of misconception categories can be seen in Table 1.

Table 1. Misconception Category [34]

\begin{tabular}{ccc}
\hline No & Percentage $(\%)$ & Category \\
\hline 1 & $0-30$ & Low \\
2 & $31-60$ & Medium \\
3 & $61-100$ & High \\
\hline
\end{tabular}

\section{RESULTS AND DISCUSSION}

The study was conducted at SMK Negeri 1 Purwasari in class X Accounting I and X Accounting II and four people were selected as research subjects with moderate written mathematical communication ability criteria. Research data obtained through interviews and essay tests on the topic of linear programming. This study aims to determine students'

136 Indonesian Journal of Science and Mathematics Education ( I J S M E ) 
misconception in solving linear programming problems reviewed from written mathematical communication ability and the causes of students' misconception. Based on the results of mathematics tests with linear programming topic, the percentage of students' misconception reviewed from written mathematical communication can be seen in Table 2.

Table 2. Students' Misconception Reviewed from Written Mathematical Communication Ability

\begin{tabular}{clccc}
\hline No & $\begin{array}{c}\text { Written mathematical } \\
\text { communication's Indicators }\end{array}$ & $\begin{array}{c}\text { The number of students } \\
\text { experiencing misconception }\end{array}$ & $\begin{array}{c}\text { Percentage } \\
(\%)\end{array}$ & $\begin{array}{c}\text { Misconception } \\
\text { Category }\end{array}$ \\
\hline 1 & $\begin{array}{l}\text { Turning Math Ideas into Math } \\
\text { Models }\end{array}$ & 3 & 75 & High \\
2 & $\begin{array}{l}\text { Choosing the Right Concept in } \\
\text { Solving Math Problems }\end{array}$ & 1 & 25 & Low \\
3 & $\begin{array}{l}\text { Representing Math Ideas into } \\
\text { Pictures or Vice Versa }\end{array}$ \\
$\begin{array}{l}\text { Write the Procedure for Solving } \\
\text { Mathematical Problems }\end{array}$ & 4 & 100 & High \\
& 3 & 75 & Low \\
\hline
\end{tabular}

Description of the misconception of research subjects (four students from Accounting class) in working on mathematical problems on linear programming topic based on indicators of written mathematical communication ability is described as follows:

\subsection{Turn Mathematical Ideas into Mathematical Models}

In this indicator, students are asked to change mathematical ideas into mathematical models, such as transforming into equations or inequalities. In this indicator some students are wrong in writing mathematical ideas into mathematical inequalities. According to the question in Table 1, students are asked to make an inequality with smaller than or equal symbol $(\leq)$, but some students change mathematical ideas into mathematical model shapes using smaller than $(<)$ or equal than $(=)$. Examples of misconceptions on research subject 1 (RS1) on indicators turning mathematical ideas into mathematical models can be seen in Figure 3.

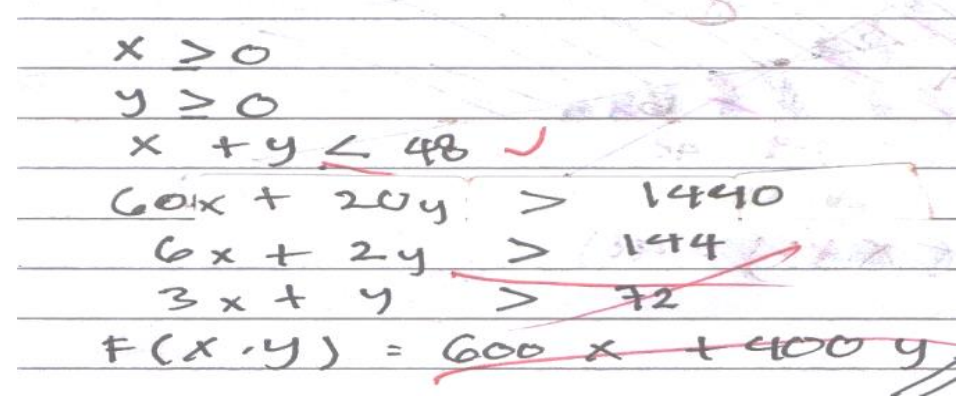

Figure 3. Misconception in Working on the First Indicator of Written Mathematical Communication

The misconception in Figure 3 is seen in the understanding of the concept of RS1 in the word "no more than" mentioned in the problem. In this problem, student's misconception is seen when student assume the word "no more than" means it must be smaller than $(<)$ and cannot be equal to $(=)$ the number on the right side. As a result, 
research subject wrote inequality with smaller than symbol $(<)$. Other misconceptions experienced by students on this indicator can be seen in Figure 4.

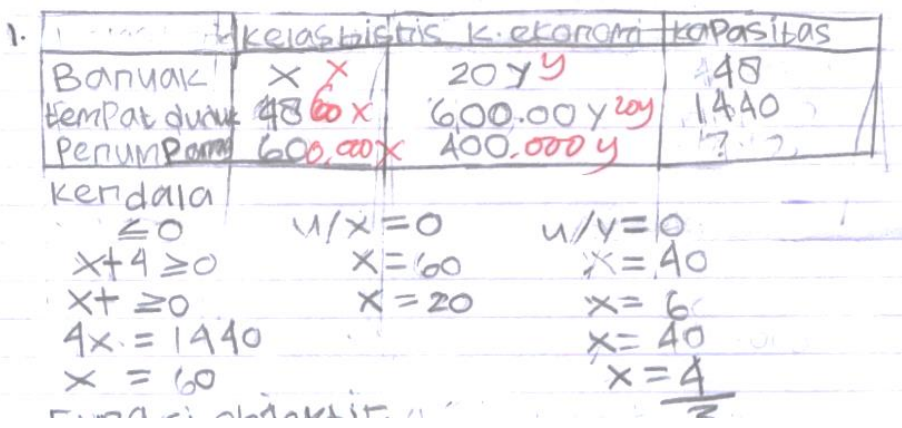

Figure 4. Research Subject 2 (RS2) Misconception on the First Indicator of Written Mathematical Communication

In Figure 4, it can be seen that RS2 misconception lies in writing the inequality symbol. RS2 wrote an inequality symbol with a more than or equal to $(\geq)$ symbol. Besides, RS2 also wrote equation symbol on mathematical models. In the case of linear programming, the equation symbol is only written on the objective function, not on the constraint function.

\subsection{Choosing the Right Concept in Solving Mathematical Problems}

In this indicator, students are asked to be able to choose the right concept in solving linear programming problems. Example of misconception experienced by RS1 on this indicator can be seen in Figure 5.

$$
\begin{aligned}
& A(0,80)=A(80,0) \\
& \begin{array}{l|l|l}
x+y=48 \\
6 x+2 y=14
\end{array} \mid \begin{array}{ll}
\text { kali } 1 & 5 x+5 y=48 \\
\text { kai } 6 & \frac{5 x+12 y=624}{0 x+17=624}
\end{array}
\end{aligned}
$$

Figure 5. SP1 Misconception on the Second Indicator of Written Mathematical Communication

The students' misconception in Figure 5 is that RS1 is not able to choose the right concept to determine the values of the variables $x$ and $y$, lthough it appears that RS1 seems to want to use the elimination method to find the values $x$ and $y$. In Figure 4 it can also be seen that RS1 experienced a misconception in calculating operations in determining the values of $x$ and $y$. Based on the results of the interview, RS1 is unable to remember the exact method in solving the problem, but RS1 can write a way to determine the values of $x$ and $y$ even though the steps shown by RS1 in eliminating variables are still wrong.

\subsection{Representing Mathematical Ideas into Pictures or Vice Versa}

In this indicator, students are asked to represent mathematical ideas into pictures or vice versa. The level of misconception on this indicator is at a high level. Here is the example of the answer from Research Subject 3 (RS3).

138 Indonesian Journal of Science and Mathematics Education ( I J S M E ) 


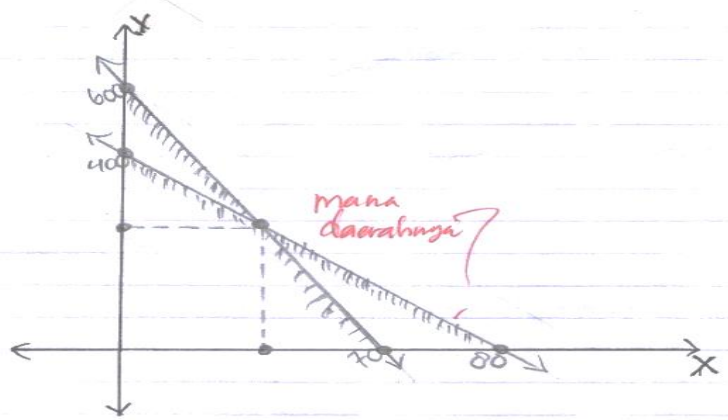

Figure 6. RS3 Misconception on the Third Indicator of Written Mathematical Communication

In Figure 6, RS3 experiences a misconception in describing the area of inequality in the cartesian curve. Through RS3 answer, it can be seen that the research subject did not fully cover the area located below the line. Besides, RS3 also did not describe the required conditions, the lines $x \geq 0$ and $y \geq 0$. This causes a misconception in determining the results area. If you look at the result of RS3 work in Table 1, you will never not know the area which is the solution of the linear program question given.

The answer of Research Subject 4 (RS4) which experiences misconception on the indicator representing mathematical ideas in to picture or vice versa, can be seen in Figure 7. Figure 7 shows that RS4 regularly shades the area which is located below the inequality line, but the shaded area remains in the quadrant I. However, the results of RS4 shading are still seen having misconception in determining the solution area. On the results, RS4 did not shade the conditions of the problem, $x \geq 0$ dan $y \geq 0$. n solving this problem, students must draw lines $x \geq 0$ dan $y \geq 0$, so that the area that is intersection inequality $x+y \leq 48,3 x+y \leq 72, x \geq 0$ and $y \geq 0$ an be seen clearly and become the solution of the indicator representing mathematical ideas into the picture becomes correct.

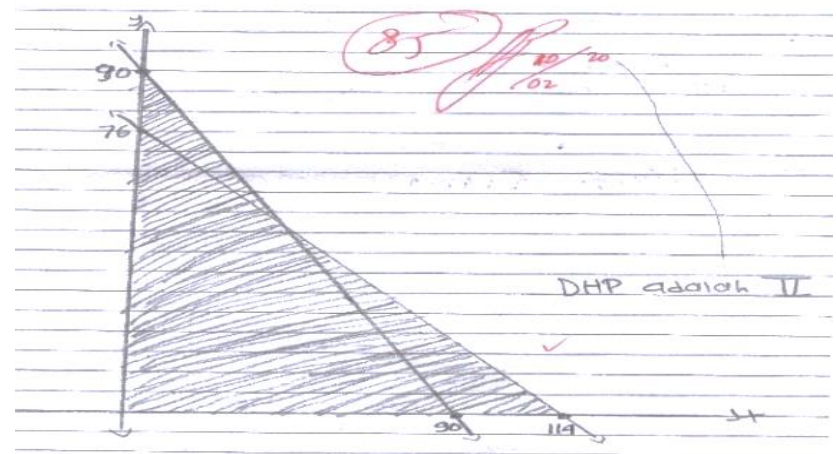

Figure 7. RS4 Misconceptionon the Third Indicator of Written Mathematical Communication

\subsection{Write Procedure for Solving Mathematical Problems}

In this indicator, students were asked to write procedures for solving problems correctly, but there are still many students experiencing misconceptions in writing the right procedures for solving linear programming problems. RS4 misconception lies in the part when the research subject uses the elimination method to determine $x$ and $y$ and when RS4 is unable to write the correct procedure to determine the optimum value of the given linear programming problem. Example of RS4 misconception in this indicator can be seen in Figure 8. 


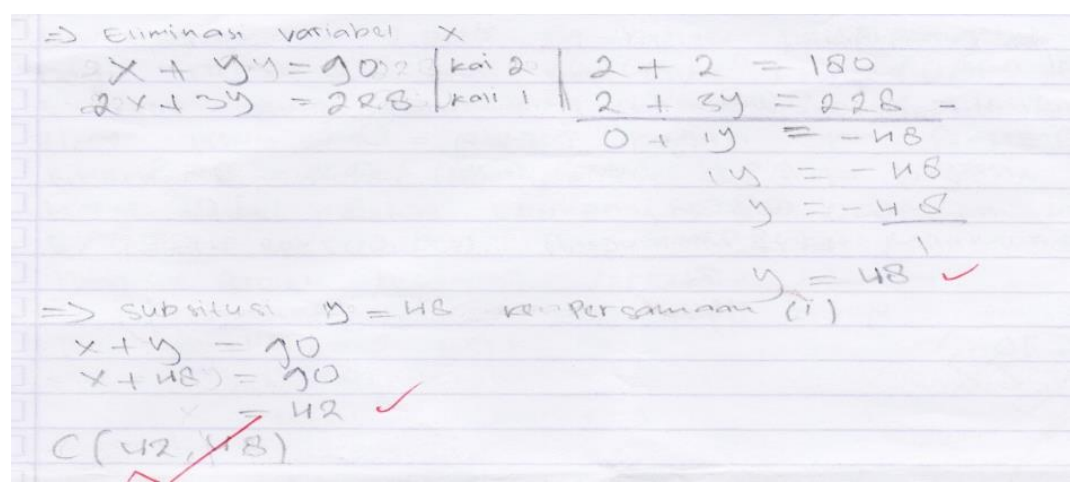

Figure 8. RS4 Misconception on the Fourth Indicator of Written Mathematical Communication

RS4 misconception in Figure 8 lies in the section when RS4 takes steps to equalize the coefficients of the $x$ variable. When RS4 multiplies the first equation by 2, it appears that RS4 has a misconception, RS4 does not write the variables $x$ and $y$ and only writes 2 . he same thing happens when RS4 writes the result of multiplying the second equation by one (1), RS4 only writes 2 without write down the $x$ variable. This also affects the value of the variable obtained.

In Figure 8, RS4 eliminates 2 and gets $y$ results from $2-3 y$ elimination results, even though the mathematical concept is $2-3 y \neq y$. In addition, RS4 also obtained a value $y=-48$, even though $y$ should be positive $(y \geq 0)$. This also affects when the research subject determines the $x$ value of the first equation. Due to an error in determining the value of $y$, RS4 also gets an incorrect $x$ result.

Based on the answers from the research subjects in completing the linear programming problems, it is known that the research subjects experienced misconceptions in each indicator. Based on the results of the interview, we got a number of reasons for misconceptions experienced by students, those are: 1) students already feel confident in the methods they use in working on the linear programming problems; 2) students' knowledge of symbols that represent inequality is wrong, and; 3) teacher teaching methods that cannot reach all students. The finding in this research is in line with the results of previous researches which state that misconceptions occur because of misunderstanding of concept in students, but students assume that the concept they understand is a truth and eventually becomes a habit, and lack of understanding of the theory, lack of ability to master mathematical symbols, lack of mastery of mathematical operations, teacher teaching methods that are incompatible with students and the incomplete information received by students, also being the causes of misconception [15], [17], [35]-[37].

In the first indicator of written mathematical communication skills, the research subjects experienced misconception in the form of errors in writing the symbol of inequality, they wrote symbols that did not match the problem. In the linear programming problem given, the research subjects were asked to interpret the word "no more than", but on the answer sheet the research subjects wrote "more than" and "equal" symbols. Based on the results of the interview, it is known that the reason research subjects experience misconceptions is because according to them, they will determine the $x$ and $y$ values of an equation, so they use the "equal" symbol so that the variable values of the equation can be solved.

In the second indicator, misconception appears when the research subject is unable to choose the right concept in determining the $x$ and $y$ values of the two equations. To determine the variable values of the two equations, research subjects can use the method

140 Indonesian Journal of Science and Mathematics Education ( I J S M E ) 
of elimination, substitution or mixed methods. Based on the results of the interview, it is known that the research subject forgot how to write the right method in solving the problem.

In the third indicator, one of the misconceptions that occurs is in determining the area of resolution of inequality. In this indicator, students shaded the area under the inequality line, so that the research subjects found the result areas are all areas that are located below the inequality line and are in quadrant I. In fact, the area that becomes the solution is the area that intersects the two inequality and remains located in quadrant I. Based on the results of interviews with research subjects, obtained information that misconceptions occur because the research subjects shaded in the same direction so students cannot determine the slices of the shading of the two inequality.

And in the fourth indicator, the research subject experienced a misconception in finding the value of the variables $\mathrm{x}$ and $\mathrm{y}$. This misconception occurs when research subjects are wrong in algebraic operations. As a result, research subjects are unable to solve problems according to appropriate procedures. Based on the results of the interview, it is known that the research subjects felt that their answers were correct, so the research subjects obtained a value from one of the variables. In addition, the research subjects also obtained the value of other variables needed because the values of the variables that had been found previously were substituted into one equation.

Through this misconception research, it is hoped that mathematics teachers are able to teach by connecting mathematical concepts with everyday life, teachers must also be able to master mathematical concepts correctly, be able to use interesting learning media so as to create interesting learning activities, and be able to connect a mathematical concept with another concept (mathematical hierarchy).

\section{CONCLUSION}

This research has clearly show that students (research subjects) experience misconceptions in solving linear program problems in terms of written mathematical communication skills. The level of research subject misconceptions in solving linear programming problems reviewed from written mathematical communication ability are in the high and low categories. High-level misconception lies in the indicator of changing mathematical ideas into mathematical models $(75 \%)$, representing mathematical ideas into pictures or vice versa $(100 \%)$, and writing the process of solving mathematical problems (75\%), while the low misconception category is found in indicator choosing the right concepts in solving mathematical problems $(25 \%)$. Srudents' misconception occur due to the lack of understanding of the right concepts of students in mastering the topic of linear programming. Besides, misconceptions in students also occur due to the inability of teachers to instill and convince students in the right concept, as a result, students repeat the wrong concept (misconception) in solving problems.

\section{REFERENCES}

[1] R. A. Pratama and A. Saregar, "Pengembangan Lembar Kerja Peserta Didik (LKPD) Berbasis Scaffolding Untuk Melatih Pemahaman Konsep," Indones. J. Sci. Math. Educ., vol. 2, no. 1, pp. 84-97, 2019.

[2] N. A. Dewanti, P. Sujatmiko, and G. Pramesti, "Analisis Pemahaman Konsep Matematika Siswa dalam Menyelesaikan Soal Faktorisasi Suku Aljabar berdasarkan Kesulitan Belajar Faktor Intelektual Siswa pada Kelas VIII B SMP N 8 Surakarrta Tahun Ajaran 2016/2017," J. Phenom., vol. 08, no. 1, pp. 26-35, 2018.

[3] O. D. P. Herawati, R. Siroj, and D. Basir, "Pengaruh Pembelajaran Problem Posing 
Terhadap Kemampuan Pemahaman Konsep Matematika Siswa Kelas XI IPA SMA Negeri 6 Palembang," J. Pendidik. Mat., vol. 4, no. 1, 2013.

[4] E. Souza de Cursi, Variational Methods for Engineers with Matlab®. Hoboken: John Wiley \& Sons, Inc, 2015.

[5] S. W. Sudarman and I. Vahlia, "Efektifitas Penggunaan Metode Pembelajaran Quantum Learning terhadap Kemampuan Pemahaman Konsep Matematis Mahasiswa," aljabar, vol. 7, no. 2, p. 276, 2016.

[6] H. Aktamis and O. Ergin, "The Effect of Scientific Process Skills Education on Students' Scientific Creativity, Science Attitudes and Academic Achievements," AsiaPacific Forum Sci. Learn. Teach., vol. 9, no. 1, p. 21, 2008.

[7] C. E. Parker, C. D. Stylinski, C. R. Bonney, J. DeLisi, J. Wong, and C. Doty, "Measuring Quality Technology Integration in Science Classrooms," J. Sci. Educ. Technol., vol. 28, no. 5, pp. 567-578, 2019.

[8] S. Latifah et al., "How the Predict-Observe-Explain (POE) learning strategy remediates students' misconception on Temperature and Heat materials?," J. Phys. Conf. Ser., vol. 1171, no. 1, pp. 1-6, 2019.

[9] J. Michael, "Misconceptions - What students think they know," Am. J. Physiol. Adv. Physiol. Educ., vol. 26, no. 1-4, pp. 5-6, 2002.

[10] M. T. H. Chi and R. d Roscoe, "The processes and challenges of conceptual change. In M. Limon \& L. Mason (Eds.)," Reconsidering Concept. Chang. Issues Theory Pract., pp. 3-27, 2002.

[11] S. . Erlwanger, "Benny " s Concept of Rules and Answers in IPI Mathematics," $J$. Child. Math. Behav., vol. 1, no. 2, pp. 7-26, 1973.

[12] H. Roselizawati $\mathrm{Hj}$ Sarwadi and M. Shahrill, 'Understanding Students' Mathematical Errors and Misconceptions: The Case of Year 11 Repeating Students," Math. Educ. Trends Res., vol. 2014, pp. 1-10, 2014.

[13] R. . Ashlock, Error patterns in computation: Using error patterns to improve instruction. New Jersey: Pearson Education, Inc, 2002.

[14] D. E. Muliani, "Penerapan Pembelajaran Konseptual Interaktif Berbantuan Media Cmaptools untuk Meminimalkan Miskonsepsi," Indones. J. Sci. Math. Educ., vol. 2, no. 3, pp. 298-302, 2019.

[15] A. H. Kurniati and Murniati, "Deskripsi Kemampuan Penalaran Matematika Siswa Ditinjau dari Pemahaman Konsep Siswa," Pedagogy, vol. 1, no. 2, pp. 38-45, 2016.

[16] W. Winarso and T. Toheri, "A Case Study of Misconceptions Students in the Learning of Mathematics; The Concept Limit Function in High School," J. Ris. Pendidik. Mat., vol. 4, no. 1, pp. 120-127, 2017.

[17] S. Aulia, N. Diana, and Yuberti, “Analisis Miskonsepsi Siswa Smp Pada Materi Fisika Analysis of Misconception of Junior High School," Indones. J. Sci. Math. Educ., vol. 1, no. 2, pp. 155-161, 2018.

[18] bambang suharto friesta ade monita, "Identifikasi dan analisis miskonsepsi siswa menggunakan three-tier multiple choice diagnostic instrument pada konsep kesetimbangan kimia," J. Inov. Pendidik. sains, vol. 7, no. 1, pp. 27-38, 2016.

[19] R. K. M. A, R. Ruslan, and H. Ihsan, "Miskonsepsi Siswa Sekolah Menengah Pertama (SMP) terhadap Bilangan Bulat, Operasi dan Sifat-Sifatnya," Intel. J. Ilmu Pendidik., vol. 1, no. 1, pp. 1-7, 2018.

[20] N. Almog and B. S. Ilany, "Absolute value inequalities: High school students' solutions and misconceptions," Educ. Stud. Math., vol. 81, no. 3, pp. 347-364, 2012.

[21] G. Edogawatte, Secondary School Students' Misconceptions in Algebra. Toronto: Department of Curriculum, Teaching, and Learning University of Toronto, 2011.

142 Indonesian Journal of Science and Mathematics Education 
[22] I. Puspitasari, R. Purwasih, A. Nurjaman, and S. Wahyuni, "Analisis Hambatan Belajar Mahasiswa Pada Mata Kuliah Program Linear," J. Ilm. Pendidik. Mat., vol. 6, no. 1, pp. 39-46, 2017.

[23] R. Hidayat and Z. B. H. Iksan, "Miskonsepsi Pada Topik Program Linear Siswa Sekolah Menengah," J. Pendidik. Mat., vol. 9, no. 1, pp. 1-9, 2015.

[24] J. Cai, M. S. Jakabcsin, and S. Lane, "Assessing Students's Mathematical Communication," Sch. Scince Math., vol. 96, no. 5, pp. 238-246, 1996.

[25] R. V Rowntree, "Students' Understandings and Misconceptions of Algebraic Inequalities," Sch. Sci. Math., vol. 109, no. 6, pp. 311-312, 2009.

[26] M. Taqiyuddin, E. Sumiaty, and A. Jupri, "Analysis of junior high school students' attempt to solve a linear inequality problem," AIP Conf. Proc., vol. 1868, no. August, pp. 050033-1-050033-12, 2017.

[27] G. Tan Sisman and M. Aksu, "A Study on Sixth Grade Students' Misconceptions and Errors in Spatial Measurement: Length, Area, and Volume," Int. J. Sci. Math. Educ., vol. 14, no. 7, pp. 1293-1319, 2016.

[28] R. Johar, "Miskonsepsi siswa sekolah dasar pada pembelajaran bilangan desimal," Sekol. Dasar, vol. 25, no. 2, pp. 160-167, 2016.

[29] S. Durst and S. R. Kaschner, "Logical Misconceptions with Conditional Statements in Early Undergraduate Mathematics," Primus, vol. 30, no. 4, pp. 367-378, 2020.

[30] B. M. Shalash, "Students " Misconceptions and Mistakes in General Mathematics Course Among Al-Quds Open University Students,” 2019.

[31] C. Vermeulen and B. Meyer, "The Equal Sign : Teachers ' Knowledge and Students 'Misconceptions The Equal Sign : Teachers ' Knowledge and Students '," African J. Res. Math. Sci. Technol. Educ., vol. 0, no. 0, pp. 1-12, 2017.

[32] D. A. Fitriani, Mardiyana, and G. Pramesti, "Analisis Miskonsepsi Siswa pada Pembelajaran Matematika Materi Pokok Ruang Dimensi Tiga Ditinjau dari Kecerdasan Visual-Spasial Siswa Kelas X Sma Negeri 1 Klaten Tahun Ajaran 2012/2013," J. Pendidik. Mat. dan Mat. Solusi, vol. 1, no. 6, pp. 27-34, 2017.

[33] T. Listiani, K. P. S. Dirgantoro, M. J. Saragih, and K. P. Tamba, "Analisis Kesalahan Mahasiswa Pendidikan Matematika Dalam Menyelesaikan Soal Geometri Pada Topik Bangun Ruang [Error Analysis of Students in the Mathematics Department in Solving Geometry Problems on the Topic of Solid Figures]," JOHME J. Holist. Math. Educ., vol. 3, no. 1, p. 44, 2019.

[34] I. P. Suwarna, "Analisis Miskonsepsi Siswa SMA Kelas X Pada Mata Pelajaran Fisika Melalui CRI (Certainty Of Response Index) Termodifikasi," J. Metlit, 2013.

[35] S. Sarlina, "Miskonsepsi Siswa terhadap Pemahaman Konsep Matematika pada Pokok Bahasan Persamaan Kuadrat Siswa Kelas X5 SMA Negeri 11 makassar," MaPan J. Mat. dan Pembelajaran, vol. 3, no. 2, pp. 194-209, 2015.

[36] E. . Ozkan and A. Ozkan, "Misconseption in Exponential Numbers in IST and IIND Level Primary School," Procedia-Social Behav. Sci., vol. 46, pp. 65-69, 2012.

[37] K. N. T, S. Subanji, and I. M. Sulandra, "Miskonsepsi Pada Penyelesaian Soal Aljabar Siswa Kelas Viii Berdasarkan Proses Berpikir Mason," J. Pendidik. - Teor. Penelitian, dan Pengemb., vol. 1, no. 10, pp. 1917-1925, 2016. 